\title{
教育講演 II＼cjkstart觜結石と萑酸代部
}

帝京大学市原

伊藤睛夫

最近、尿路結石の成因についての分子生物学的研究が進み、より根本的な形成メカニズムが明らかに なりつつある。しかし、現時点においては24㭙間蓄尿中の尿路結石関連物質の定量結果が結石形成ある いは再発の危険因子あるいは治療の目安とされている。今回は結石の成分としては葆酸カルシウム結石 に限定し、また、尿中の高分子抑制物質には触れないことにする。

危険因子としては結石の素材であるカルシウムおよび葆酸が多く排泄される高カルシウム尿と高修酸 尿、およびこれに影響を与える高尿酸尿、低クエン酸尿、低マグネシウム尿等があげられる。これらの うちでは最近までカルシウム尿に関心が集まっていた。しかし、われわれの開放手術後およびESWL後 の結石の再発を見ると高カルシウム尿の有無は再発率に影響を与えていない。これに対して、高葆酸尿 群は高葆酸尿を認めない群に比して、再発が多いといらことが判明した。

腸性高萑酸尿症患者に対してカルシウム剂の投与を行なうと尿中カルシウムは軽度上昨したが、尿中 萑酸は減少し、結石形成は見られなくなった。これは尿中カルシウムは軽度上鼎してむ、尿中葆酸が減 少すれば良い結果が得られることを示唆するものと思われる。カルシウム結石患者の栄羪摄取状況につ いてみてみると、日本人のカルシウム所要量に比して結石患者のカルシウム揸取が不足していることが 判明した。同時に蛋白質と脂質の攝取が多いことが分かった。再発群と非再発群を比べると再発群のほ うが蛋白摄取が多い。

われわれが結石患者における食事内容の分析結果と尿中萑酸排泄量との関係を調べたところ、カルシウ 厶摂取量が多いと葆酸排泄量は減少し、逆に脂肪の椇取量が多いと葆酸排泄量は多くなるといら結果で あった。高カルシウム尿は結石再発の少なくとも重要な危険因子とは言えないことより、カルシウム㓩 の投与を行なった。乳酸カルシウム $3 \mathrm{~g} / \mathrm{day}$ であるので、カルシウムとしては約 $390 \mathrm{mg} / \mathrm{day}$ である。すると、 尿中葆酸は減少することが分かった。さらに，カルシウム多量掑取を勧める食事指導によりESWL後の 結石の再発率が減少することが分かった。

一方、尿路結石と関連して、食事中の葆酸がどの位の割合で吸収されるかについての研究はなされて きたが、食物中の葆酸が腸管内でどの程度分解されるかについての検討はほとんど行なわれていなかっ た。われわれの検討でヒト烡便は蓉酸分解活性を有していることが分かり、この活性は結石患者で低い ことが示唆された。そこで、われわれはヒト䔬便を炭素源が葆酸のみの培地で長期継代し、ペニシリン 添加、葆酸除去の培地で蕽樎した。これをBarber培地の改変寒天培地にプレーテイングし得られたコロ ニーの蓚酸分解能を調ベ、葆酸分解菌を得た。この菌は性状検査、およびDNA-DNA ハイブリダイゼー ション法による遗伝子による分類でEubacteriumlentum（Eubacteriumentum WYH-1と命名）であること が判明した。このように、腸管内の葆酸分解菌の異常が特発性の腎結石形成の一因である可能性もあり うるであろう。この菌体より葆酸分解䣼の精製を行ったのでその結果についても報告する。

以上より尿中葆酸が最む重要な危険因子と考えられ、これを減少させることが再発を防止する要であ ると考えられる。このためには食事療法が一番効果的と思われる。最近まで勧められていたカルシウム および蚠白質の掑取制限に代わり脂肪椇取制限とカルシウム多量撕取が有効と考えられる。 